\title{
Differential expression of genes in salivary glands of male Rhipicephalus (Boophilus)microplus in response to infection with Anaplasma marginale
}

Zorica Zivkovic ${ }^{1 *}$, Eliane Esteves ${ }^{2}$, Consuelo Almazán ${ }^{3}$, Sirlei Daffre ${ }^{2}$, Ard M Nijhof ${ }^{1}$, Katherine M Kocan ${ }^{4}$, Frans Jongejan ${ }^{1,5}$, José de la Fuente ${ }^{4,6}$

\begin{abstract}
Background: Bovine anaplasmosis, caused by the rickettsial tick-borne pathogen Anaplasma marginale (Rickettsiales: Anaplasmataceae), is vectored by Rhipicephalus (Boophilus)microplus in many tropical and subtropical regions of the world. A. marginale undergoes a complex developmental cycle in ticks which results in infection of salivary glands from where the pathogen is transmitted to cattle. In previous studies, we reported modification of gene expression in Dermacentor variabilis and cultured Ixodes scapularis tick cells in response to infection with A. marginale. In these studies, we extended these findings by use of a functional genomics approach to identify genes differentially expressed in R. microplus male salivary glands in response to A. marginale infection. Additionally, a $R$. microplus-derived cell line, BME26, was used for the first time to also study tick cell gene expression in response to $A$. marginale infection.

Results: Suppression subtractive hybridization libraries were constructed from infected and uninfected ticks and used to identify genes differentially expressed in male $R$. microplus salivary glands infected with A. marginale. A total of 279 ESTs were identified as candidate differentially expressed genes. Of these, five genes encoding for putative histamine-binding protein (22Hbp), von Willebrand factor (94Will), flagelliform silk protein (100Silk), Kunitzlike protease inhibitor precursor (108Kunz) and proline-rich protein BstNI subfamily 3 precursor (7BstNI3) were confirmed by real-time RT-PCR to be down-regulated in tick salivary glands infected with A. marginale. The impact of selected tick genes on A. marginale infections in tick salivary glands and BME26 cells was characterized by RNA interference. Silencing of the gene encoding for putative flagelliform silk protein (100Silk) resulted in reduced $A$. marginale infection in both tick salivary glands and cultured BME26 cells, while silencing of the gene encoding for subolesin (4D8) significantly reduced infection only in cultured BME26 cells. The knockdown of the gene encoding for putative metallothionein (93 Meth), significantly up-regulated in infected cultured BME26 cells, resulted in higher A. marginale infection levels in tick cells.

Conclusions: Characterization of differential gene expression in salivary glands of $R$. microplus in response to A. marginale infection expands our understanding of the molecular mechanisms at the tick-pathogen interface. Functional studies suggested that differentially expressed genes encoding for subolesin, putative von Willebrand factor and flagelliform silk protein could play a role in A. marginale infection and multiplication in ticks. These tick genes found to be functionally relevant for tick-pathogen interactions will likely be candidates for development of vaccines designed for control of both ticks and tick-borne pathogens.
\end{abstract}

\footnotetext{
* Correspondence: Z.Zivkovic@uu.nl

${ }^{1}$ Department of Infectious Diseases and Immunology, Utrecht Centre for

Tick-borne Diseases (UCTD), Faculty of Veterinary Medicine, Utrecht

University, Yalelaan 1, 3584CL, Utrecht, the Netherlands
}

(C) 2010 Zivkovic et al; licensee BioMed Central Ltd. This is an Open Access article distributed under the terms of the Creative Commons 


\section{Background}

Bovine anaplasmosis, caused by the obligate intracellular rickettsial pathogen, Anaplasma marginale (Rickettsiales: Anaplasmataceae), is characterized in cattle by anemia, fever, weight loss and reduced milk production [1]. Transmission of $A$. marginale occurs mechanically by biting flies and blood-contaminated fomites, while ticks are biological vectors [2]. Approximately 20 tick species have been incriminated worldwide as vectors of A. marginale [2]. Of these tick species, the southern cattle tick, Rhipicephalus (Boophilus)microplus, found in tropical and subtropical regions of the world, is considered to be the most economically important ectoparasite of livestock [3]. R. microplus vectors several pathogens and $A$. marginale is among the most important, causing notable economic loss in milk and beef production [4].

The developmental cycle of $A$. marginale was described in Dermacentor ticks, and male ticks were shown to become persistently infected with $A$. marginale and able to transmit infection repeatedly when transferred among cattle [5]. The A. marginale development, multiplication in the tick and transmission to the vertebrate host are coordinated with tick feeding. Within Dermacentor ticks, A. marginale undergoes a complex developmental cycle that begins with the infection of the gut cells. After a second tick feeding, many other tick tissues become infected, including the salivary glands from where the $A$. marginale is transmitted to cattle [6]. Although the developmental cycle of A. marginale has not been described for Rhipicephalus (Boophilus) spp., the developmental cycle in R. microplus is most likely similar and males may also play an important role in pathogen transmission [7].

Molecular interactions at the tick-pathogen interface ensure survival and development of both the pathogen and vector. While recent studies on several pathogens have demonstrated that tick gene expression is modified in response to pathogen infection [8-10], information on the function of the differentially expressed genes is limited [11]. RNA interference (RNAi) has been shown to be a useful tool for the characterization of the function of genes involved in tick-host-pathogen interactions and the transmission of tick-borne pathogens and for screening for tick protective antigens [11]. Recently, genes differentially expressed in cultured IDE8 tick cells in response to A. marginale infection were identified and their impact on pathogen infection in D. variabilis ticks was characterized by RNAi during the pathogen developmental cycle [11].

Tick cell lines have been used successfully to study vector-pathogen interactions [12]. However, these studies were conducted in the IDE8 and ISE6 tick cell lines derived from Ixodes scapularis embryos which is not a natural vector of $A$. marginale [12]. Recently, a Brazilian isolate of $A$. marginale was propagated successfully in the
BME26 cell line derived from $R$. microplus [13] which provided the opportunity to study the $A$. marginale-tick interface in the cells cultured from a natural tick vector.

The objective of this study was to identify $R$. microplus genes differentially expressed in male salivary glands in response to infection with $A$. marginale by using suppression subtractive hybridization ( $\mathrm{SSH}$ ) approach and to characterize the function of those genes by RNAi. SSH enables identification of low-abundant rare transcripts through the comparison of two cDNA populations by selective amplification of the genes expressed in one population but not in the other $[14,15]$. The results of these SSH studies were validated by real-time RT-PCR in R.microplus ticks and cultured BME26 tick cells for selected genes. Finally, functional analyses were conducted on selected genes by RNAi in both $R$. microplus male ticks and cultured BME26 cells to determine the putative role of these genes in A. marginale-tick interactions.

\section{Results}

Identification of differentially expressed genes in R. microplus male salivary glands

Two SSH libraries, forward and reverse, were constructed to identify genes up- and down-regulated in $R$. microplus male salivary glands in response to A. marginale infection. From each library, 288 randomly selected clones were identified and sequenced. After removing vector sequences and eliminating EST clones with poor sequence quality, datasets of 128 and 151 ESTs from forward and reverse subtracted libraries were obtained, respectively, and used for bioinformatics analyses. Clustering and assembly of ESTs from forward subtracted library (up-regulated in infected cells) resulted in 43 unique transcripts of which 10 were derived from two or more ESTs (consensus sequences) and 33 were derived from a single EST (singletons). Assembly of the ESTs in the reverse subtracted library (down-regulated in infected cells) yielded 56 unique sequences (24 consensus sequences and 32 singletons). Automated annotation was then used to search public domain protein databases for putative functions (Additional file 1: Table S1). Gene ontology assignments demonstrated that up-regulated genes encoded for proteins with putative functions of binding (21\%), structural molecules (11\%), catalytic/enzymatic activity (6\%), DNA/ RNA metabolism (4\%), and $58 \%$ had no known function (Figure 1A). Putative functions assigned to down-regulated genes included binding (20\%), structural molecules (20\%), catalytic/enzymatic activity (7\%), transport (5\%) and 48\% had no known function (Figure 1B).

\section{Differential gene expression in A. marginale-infected} R. microplus male salivary glands and cultured BME26 cells Fourteen candidate genes with putative functions in tick-pathogen interactions were selected for validation 


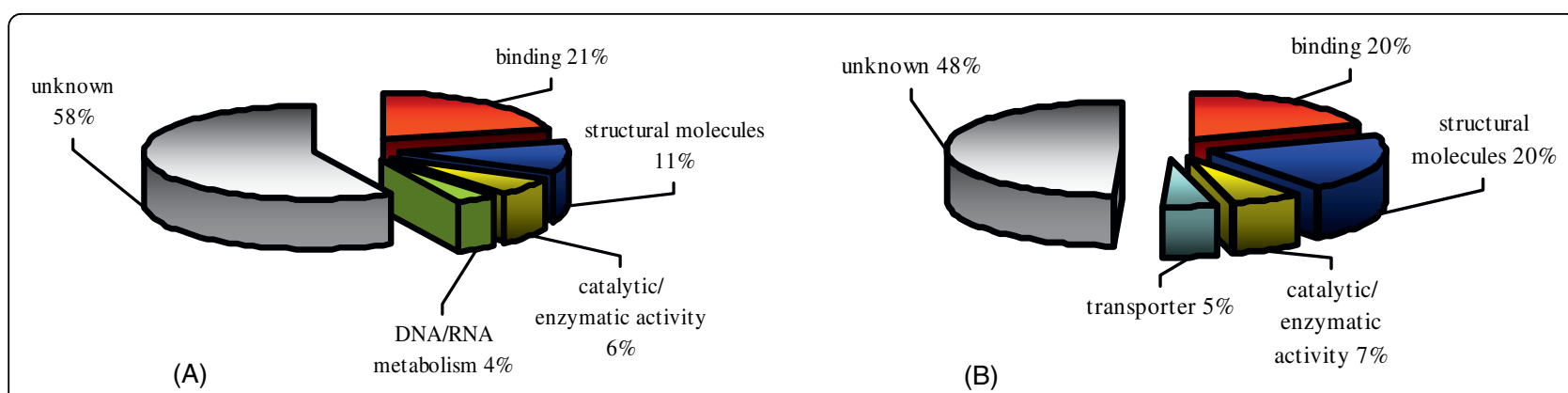

Figure 1 Gene ontology assignments of ESTs differentially expressed in $R$. microplus male salivary glands in response to $A$. marginale infection. (A) Genes up-regulated in infected salivary glands. (B) Genes down-regulated in infected salivary glands.

of SSH results by real-time RT-PCR (Additional file 2: Table S2). Real-time RT-PCR analyses were done on the same pooled RNA samples used for SSH. Statistically significant differences in expression were obtained for 5 genes (Figure 2). Similar to the SSH results, genes encoding for putative female-specific histamine-binding protein $(22 \mathrm{Hbp})$, flagelliform silk protein (100Silk), Kunitz-like protease inhibitor precursor (108Kunz), and proline-rich protein BstNI subfamily 3 precursor (7BstNI3) were significantly down-regulated in infected tick salivary glands. The gene encoding for the putative von Willebrand factor (94Will), identified to be up-regulated by SSH, was shown by real-time RT-PCR to be significantly down-regulated in the infected tick salivary glands. For the other 9 genes, mRNA levels were not significantly different between infected and uninfected ticks.

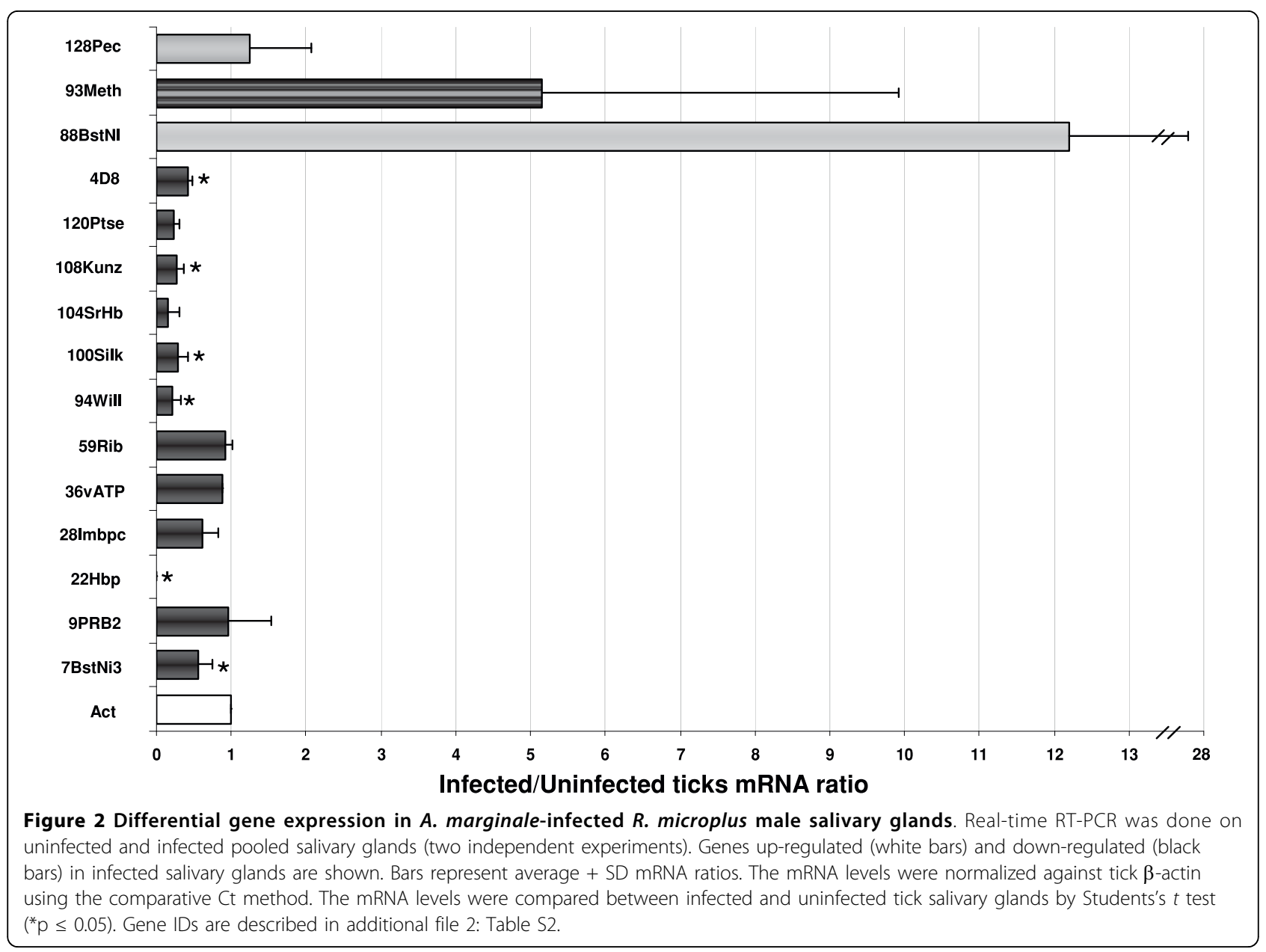


Subolesin (4D8), used as a positive control, was downregulated in $A$. marginale-infected tick salivary glands.

To evaluate the use of cultured BME26 cells for studying $A$. marginale-tick interactions, the same primers were used for real-time RT-PCR analysis of uninfected and $A$. marginale-infected BME26 tick cells. Twelve of the 14 selected genes were amplified from BME26 cultured cells. Gene expression profiles were studied for each gene at 6, 24 and 72 hours post-infection (hpi) and compared with uninfected cells collected at the same time points (Figure 3). Genes encoding for putative vacuolar $\mathrm{H}+$-ATPase (36vATP) and ribosomal protein S29 (59Rib) were significantly up-regulated at $6 \mathrm{hpi}$, while putative Kunitz-like protease inhibitor precursor (108Kunz), metallothionein (93 Meth) and von Willebrand factor (94Will) were significantly up-regulated 24 and $72 \mathrm{hpi}$. The mRNA levels for the rest of the genes were not statistically different between infected and uninfected BME26 cells. The subolesin (4D8) control was significantly downregulated by $24 \mathrm{hpi}$.

All the tick sequence-derived primers were tested against bovine RNA by RT-PCR. Amplicons were not obtained for any of the primer pair tested (data not shown).
Functional roles of genes differentially expressed in R. microplus ticks and cultured BME26 cells in response to infection with $A$. marginale

The five genes corroborated by real-time RT-PCR to be differentially expressed in $A$. marginale infected tick salivary glands, female-specific histamine-binding protein (22Hbp), flagelliform silk protein (100Silk), Kunitz-like protease inhibitor precursor (108Kunz), proline-rich protein BstNI subfamily 3 precursor (7BstNI3) and von Willebrand factor (94Will) (Figure 2), were selected for functional analyses in ticks. The effect of gene knockdown on $A$. marginale infection and multiplication in $R$. microplus male tick salivary glands was evaluated by RNAi. The mRNA levels after RNAi were reduced for putative von Willebrand factor (94Will), flagelliform silk protein (100Silk) and subolesin (4D8), while silencing of the other genes did not result in statistically significant differences from the control (Table 1).

The effect of RNAi of selected genes on male $B$. microplus mortality was determined. Tick mortality was significantly higher in groups injected with dsRNA for von Willebrand factor (94Will), flagelliform silk protein (100Silk) and subolesin when compared with the unrelated dsRNA-injected control ticks (Table 1). Despite

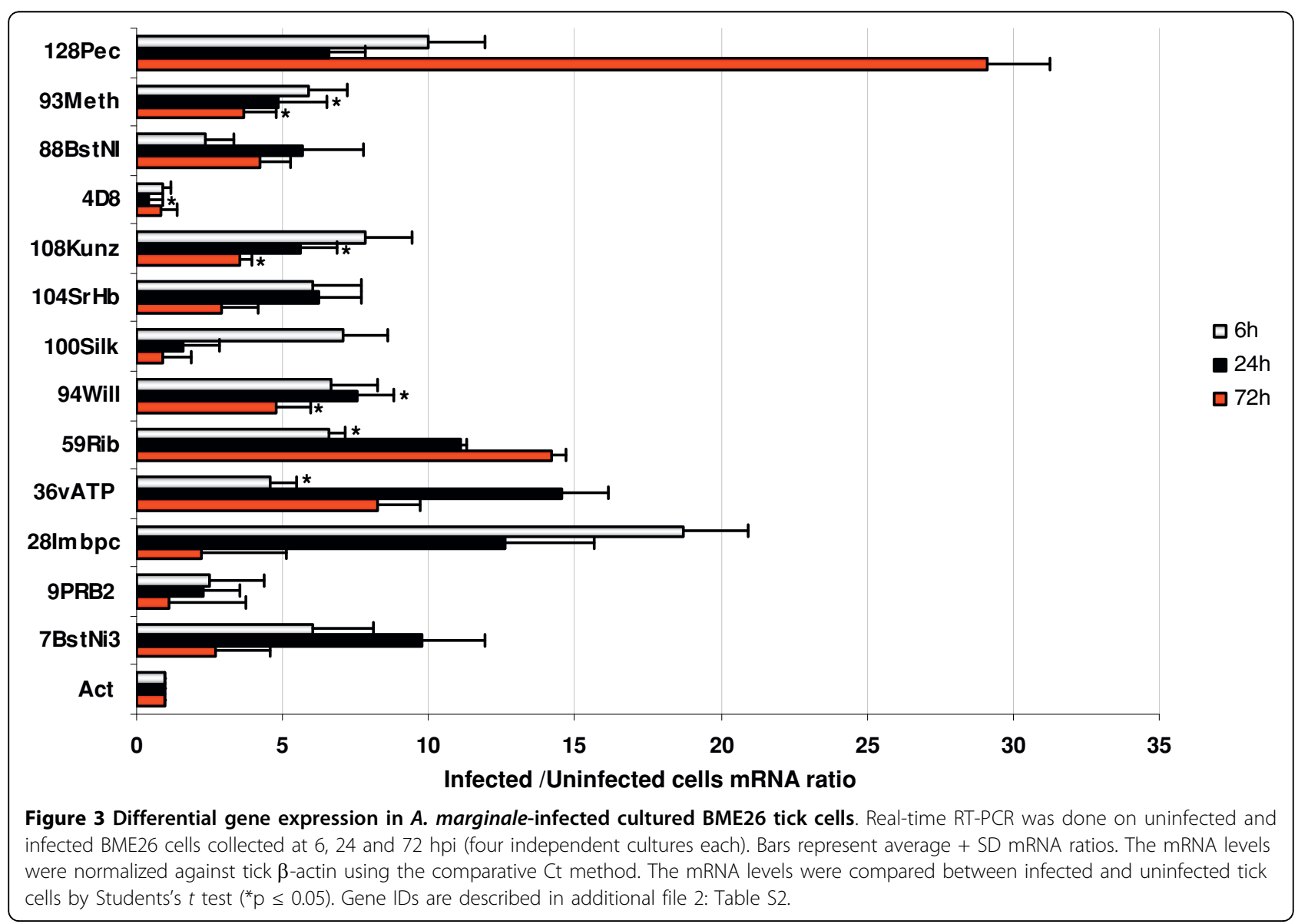


Table 1 A. marginale infection levels in tick salivary glands after RNAi and tick mortality rates in dsRNA-injected $R$. microplus males

\begin{tabular}{lccc}
\hline $\begin{array}{l}\text { Experimental } \\
\text { group }\end{array}$ & $\begin{array}{c}\text { Gene } \\
\text { expression } \\
\text { silencing } \\
(\%) \pm \text { SD }^{\mathbf{a}}\end{array}$ & $\begin{array}{c}\text { A. marginale infection } \\
\text { levels (\% change with } \\
\text { respect to controls) }\end{array}$ & $\begin{array}{c}\text { Mortality } \\
\text { rate }^{\mathbf{b}}\end{array}$ \\
\hline 94Will & $85.6 \pm 16.9$ & $29.4 \pm 0.6(-63 \%)$ & $80 \%^{* *}$ \\
\hline 100Silk & $89.8 \pm 9.4$ & $17.0 \pm 1.1(-79 \%)^{*}$ & $74.3 \%^{* *}$ \\
\hline $\begin{array}{l}\text { Subolesin } \\
\text { (4D8) }\end{array}$ & $82.7 \pm 12.7$ & $32.0 \pm 1.6(-60 \%)$ & $68.6 \%^{* *}$ \\
\hline Control & - & $80.0 \pm 1.9$ & $57.1 \%$ \\
\hline
\end{tabular}

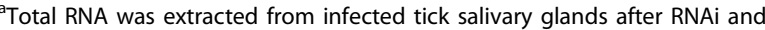
analyzed by real-time RT-PCR to determine gene expression silencing with respect to control ticks injected with the GIII dsRNA

${ }^{\mathrm{b}}$ The $A$. marginale infection levels were analyzed by msp4 PCR, expressed as msp4 copies per tick \pm SD and compared between test and control ticks injected with the GIII dsRNA by Student's $t$ test $\left({ }^{*} p<0.05\right)$.

'Tick mortality was evaluated as the ratio of dead male ticks 7 days after dsRNA injection to the total number of the attached male ticks, and was compared between test and control ticks injected with the GIII dsRNA by $\chi^{2}$-test $\left({ }^{* *} \alpha<0.025\right)$

the fact that individual variation in gene expression affected the statistical significance of results, silencing of the genes encoding for putative von Willebrand factor (94Will), flagelliform silk protein (100Silk) and subolesin (4D8) resulted in $63 \%, 79 \%$ and $60 \%$ decrease in $A$. marginale infection levels in $R$. microplus male salivary glands, respectively (Table 1 ). Characterization of the effect of gene knockdown on A. marginale infections in cultured BME26 tick cells was attempted for all the genes which were shown to be differentially expressed in tick cells and/or tick salivary glands. However, mRNA levels were reduced only for putative ribosomal protein S29 (59Rib), metallothionein (93 Meth), flagelliform silk protein (100Silk) and subolesin (4D8) genes (Table 2). Of these genes, two genes encoding for putative flagelliform silk protein (100Silk) and subolesin resulted in $12 \%$ and $17 \%$ reduction of $A$. marginale infection levels, respectively, when compared with controls (Table 2). The knockdown of the gene encoding for putative metallothionein (93 Meth) resulted in higher A. marginale infection levels in tick cells (Table 2).

\section{Discussion}

In the present study we identified $R$. microplus male salivary gland genes differentially expressed in response to A. marginale infection by use of SSH and real-time RT-PCR. Development and multiplication of A. marginale in salivary gland cells involves molecular interactions between pathogen- and tick-derived molecules. Salivary gland, the tissue of interest in this study, is a critical site in the developmental cycle from where the pathogen is transmitted to cattle. Recently, tick salivary gland proteins were shown to play a role in the infection and
Table 2 A. marginale infection levels in cultured BME26 tick cells after RNAi

\begin{tabular}{ccc}
\hline $\begin{array}{c}\text { Experimental } \\
\text { group }\end{array}$ & $\begin{array}{c}\text { Silencing of gene } \\
\text { expression } \\
(\%) \pm \text { SD }^{\mathbf{a}}\end{array}$ & $\begin{array}{c}\text { A. marginale infection } \\
\text { levels }\end{array}$ \\
\hline $\begin{array}{c}\% \text { change with respect } \\
\text { to controls) }\end{array}$ \\
\hline 59 Rib & $71.7 \pm 31.1$ & $8.6 \pm 0.5(-3 \%)$ \\
\hline 93 Meth & $65.0 \pm 14.4$ & $18.0 \pm 0.0(+102 \%)^{*}$ \\
\hline 100Silk & $99.5 \pm 0.3$ & $7.8 \pm 0.6(-12 \%)^{*}$ \\
\hline $\begin{array}{c}\text { Subolesin } \\
\text { (4D8) }\end{array}$ & $88.1 \pm 7.1$ & $7.4 \pm 0.3(-17 \%)^{*}$ \\
\hline Control & - & $8.9 \pm 1.4$ \\
\hline
\end{tabular}

aTotal RNA was extracted from infected tick cells after RNAi and analyzed by real-time RT-PCR to determine gene expression silencing with respect to control cells treated with buffer only.

${ }^{\mathrm{b}}$ The $A$. marginale infection levels were analyzed by msp4 PCR, expressed as msp4 DNA (ng) \pm SD and compared between test and control ticks by Student's $t$ test $\left({ }^{*} p<0.05\right)$

transmission of Borrelia burgdorferi [16,17], A. phagocytophilum [18] and A. marginale [19]. A. marginale membrane surface proteins involved in tick salivary gland colonization have been identified and partially characterized [20,21]. Understanding the molecular mechanisms of $A$. marginale-tick interactions for $R$. microplus, one of the most important vectors of $A$. marginale worldwide, is fundamental toward development of novel control measures [22].

Some of the genes identified by SSH, including those genes encoding for putative tick cement proteins, female specific histamine binding protein, IgG binding protein $\mathrm{C}$, salivary gland-associated protein $64 \mathrm{P}$, flagelliform silk protein and von Willebrand factor, were identified previously in different tick species and appear to be involved in tick feeding or pathogen infection [10,23-25]. However, most of the differentially expressed genes identified in this study have not been shown to be associated with tick-pathogen interaction previously. Some cellular functions affected by $A$. marginale infection of $R$. microplus, such as cell structure and enzymatic processes, were reported previously in infected tick IDE8 cultured cells [11]. The discrepancy observed for some studied genes between SSH and real-time RTPCR results may reflect differences between both methods for identifying differentially expressed genes or the presence of multiple sequences targeted during RT-PCR reactions that affect the results of mRNA quantification for some genes.

In a recent study, genes differentially expressed in cultured IDE8 tick cells in response to A. marginale infection were identified and functional studies conducted in $D$. variabilis suggested that these genes may play different roles during pathogen infection, development and trafficking from midguts to salivary glands [11]. Some of the genes identified by de la Fuente et al. [11] such as gluthathione S-tranferase, selenoprotein $\mathrm{M}$ and ferritin 
were also shown to be differentially expressed in $R$. microplus salivary glands in response to $A$. marginale infection. However, these genes were absent from the current EST dataset which could be due to differences in the system used for EST discovery (cultured IDE8 tick cells versus $R$. microplus salivary glands) and/or other factors such as tick species and/or A. marginale strain and infection levels.

While tick cell lines have been used successfully in A. marginale functional genomics studies [11], this is the first report of the use of the BME26 tick cell line derived originally from a natural vector of $A$. marginale for functional studies of tick-pathogen interactions. Since these studies were conducted on ticks and tick cells of the same species, most of the genes identified in tick salivary glands were also amplified from cultured BME26 tick cells. However, expression profiles of selected genes observed in cultured BME26 cells were not identical to that found in tick salivary glands. For example, the expression of the putative von Willebrand factor (94Will) was down-regulated in tick salivary glands but up-regulated in cultured BME26 tick cells infected with $A$. marginale. These differences may have resulted from tissue-specific regulation of gene expression or because we only observed early stages of infection in the cultured BME26 tick cells (6-72 hpi). As reported previously [11], results of studies using cultured tick cells must be validated in naturally infected ticks. Interestingly, expression of putative vacuolar $\mathrm{H+-}$ ATPase (36vATP) was significantly up-regulated in A. marginale-infected cultured BME26 cells, as reported for previous gene expression studies of cultured IDE8 cells in response to A. marginale infection [11].

RNAi was used in this study to assign the effect of selected gene knockdown on $A$. marginale infection and multiplication in ticks. Although statistically significant for flagelliform silk protein (100Silk) only, results of RNAi experiments suggested that putative von Willebrand factor (94Will), flagelliform silk protein (100Silk) and subolesin could play a role in pathogen infection of $R$. microplus male salivary glands. RNAi experiments in cultured BME26 tick cells provided further evidence that flagelliform silk protein (100Silk) and subolesin may play a role in $A$. marginale infection and/or multiplication in tick cells and suggested that metallothionein (93 Meth) may be involved tick defense against pathogen infection.

The flagelliform silk protein was identified previously in tick and orb weaving spider salivary glands but its function was not linked to pathogen infection [26-28]. Mulenga et al. [29] demonstrated that the flagelliform silk protein may be involved in tick attachment. In previous studies of $I$. ricinus after B. burgdorferi infection, the von Willebrand factor was isolated from tick salivary glands and shown to be up-regulated but its possible role in infection was not studied [10]. A von Willebrand factor-like motif is present in the major hemelipoglycoprotein found in ixodid ticks and this protein has been shown to play a role as a heme-sequestering factor during tick feeding [30]. Therefore, silencing of these genes may affect tick feeding, mortality and development of A. marginale in salivary glands. However, as shown previously for subolesin [19], gene expression studies in cultured BME26 tick cells have provided evidence that that the flagelliform silk protein may play a role in the infection of ticks with A. marginale.

The results for gene expression and silencing of subolesin in R. microplus male salivary glands and cultured BME26 cells infected with $A$. marginale reported herein are in agreement with previous studies in which subolesin knockdown reduced $A$. marginale infection in D. variabilis and cultured IDE8 cells $[11,19]$. Subolesin, discovered as a tick protective antigen in I. scapularis, has been shown to be conserved in many tick species $[31,32]$. Subolesin was shown by both RNAi gene knockdown and immunization trials using the recombinant protein to protect vertebrate hosts against tick infestations, reduce tick survival and reproduction, and cause degeneration of gut, salivary gland, reproductive tissues and embryos [31-37]. Targeting of subolesin by RNAi or vaccination also decreased tick vector capacity for A. marginale and A. phagocytophilum [19]. In addition, subolesin was shown to function in the control of gene expression in ticks $[38,39]$ and to be differentially expressed in Anaplasma-infected ticks and cultures tick cells $[11,40]$. However, subolesin expression in $R$. microplus tick salivary glands and cultured BME26 cells was different to previous reports showing up-regulation in A. marginale-infected $D$. variabilis salivary glands and cultured IDE8 cells [41]. These differences could be due to tick species-specific differences in gene regulation or to other factors such as pathogen strain and infection levels. Nonetheless, these results expanded our knowledge on the role of subolesin in tick-Anaplasma interactions.

Metallothioneins are a family of low molecular weight proteins with a high affinity for divalent metals that function in cell detoxification, apoptosis, stress response and immunity [41-43]. Metallothioneins control the cellular zinc ion levels, which are known to be important in the immune system, and their expression has been associated with protective response against pathogens [44-48]. The results suggested a role for tick metallothioneins in defense against bacterial infections. Interestingly, selenoproteins that regulate the levels of another important trace mineral in the organism were suggested to participate in the cellular response to limit A. marginale infection in tick cells [11]. 
Although dsRNA sequences used in this study do not contain any significant overlap with other known $R$. microplus genes, the possibility of off-target gene silencing effects cannot be excluded due to the limited amount of sequence data available. However, RNAi seems to be very sequence-specific in ticks with little off-target effects [38]. Availability of the complete $R$. microplus genome sequence data will facilitate screening for potential off-target effects. These can subsequently be minimized by avoiding the use of dsRNAs or siRNAs containing sequences which are present in multiple genes.

In our study $R$. microplus male salivary gland genes differentially expressed in response to $A$. marginale infection were identified by using $\mathrm{SSH}$ approach. Recently a $R$. microplus microarray (NimbleGen) has been developed and used for the analysis of acaricideinducible genes in $R$. microplus [49]. Microarray chip hybridization could be an alternative approach for identifying $R$. microplus differentially expressed genes in response to $A$. marginale infection.

\section{Conclusions}

In this study, A. marginale infection of $R$. microplus was shown to modulate in male salivary glands the expression of genes encoding for putative proteins involved in binding, catalytic/enzymatic activity, transport, DNA/ RNA metabolism and structural molecules. Five genes encoding for putative histamine-binding protein (22Hbp), von Willebrand factor (94Will), flagelliform silk protein (100Silk), Kunitz-like protease inhibitor precursor (108Kunz) and proline-rich protein BstNI subfamily 3 precursor (7BstNI3) were confirmed by realtime RT-PCR to be down-regulated in tick salivary glands infected with $A$. marginale. Functional studies suggested that differentially expressed genes encoding for subolesin, putative von Willebrand factor and flagelliform silk protein could play a role in A. marginale infection and multiplication in ticks. Additionally, for the first time RNAi in cultured BME26 tick cells was used to study $A$. marginale-tick molecular interactions and suggested that subolesin and flagelliform silk protein may be required by $A$. marginale for infection and multiplication in these cultured cells. Collectively these data are important toward understanding the molecular mechanisms involved in $R$. microplus-A. marginale interactions.

\section{Methods}

\section{Experiment design}

A suppression subtractive hybridization ( $\mathrm{SSH}$ ) approach was used to identify genes differentially expressed in $R$. microplus male salivary gland genes in response to A. marginale infection. Sequences obtained by $\mathrm{SSH}$ were used to search for homology/identity to nucleotide and protein databases. Real-time RT-PCR was used to validate differential expression of selected genes in uninfected and $A$. marginale-infected $R$. microplus salivary glands. Differential expression patterns of selected genes were also studied in cultured BME26 cells at 6, 24 and 72 hpi by real-time RT-PCR. The genes that proved to have significantly different mRNA levels between uninfected and $A$. marginale-infected ticks or cultured BME26 tick cells were then selected for functional studies. RNAi was used to characterize the function of selected genes in $A$. marginale infection in vivo in $R$. microplus male ticks and in vitro in cultured BME26 tick cells.

\section{Rhipicephalus microplus ticks}

The $R$. microplus ticks used for construction of the SSH libraries originated from Mozambique and were provided by ClinVet International (Pty), Bloemfontein, South Africa. The R. microplus (Susceptible, CENAPA, Mexico strain) ticks used for the RNAi experiments were obtained from laboratory colonies maintained at the University of Tamaulipas, Mexico. Originally, these tick strains were collected from infested cattle in Tapalpa, Jalisco, Mexico. The ticks were maintained on cattle at the tick rearing facilities at the Utrecht Center for Tick-Borne Diseases, Utrecht University or the University of Tamaulipas. Larvae were kept off-host in an incubator at $20^{\circ} \mathrm{C}$ with $95 \%$ relative humidity and 12 hours light: 12 hours dark photoperiod. Cattle were cared for in both The Netherlands and Mexico in accordance with standards specified in the Guide for Care and Use of Laboratory Animals.

\section{Tick cell line}

The tick cell line BME26 was derived originally from embryos of $R$. microplus following the protocol established by Kurrti et al[50]. The cells were maintained in L-15B300 medium [51] supplemented with 5\% heatinactivated FBS (Gibco/Invitrogen, NY, USA), 10\% TPB (Difco, Detroid, MI, USA), 0,1\% bovine lipoprotein (ICN, Irvine, CA), 100 units $\mathrm{ml}^{-1}$ penicillin (Gibco/Invitrogen) and $100 \mathrm{~g} \mathrm{~m} \mathrm{~m}^{-1}$ streptomycin (Gibco/Invitrogen) at $\mathrm{pH} 7.2$. Cultures were grown at $34^{\circ} \mathrm{C}$ in $25 \mathrm{~cm}^{2}$ plastic flasks (Nalge Nunc Int. Rochester, NY) containing $5 \mathrm{ml}$ of the complete medium, which was changed weekly. Monolayers were subcultured when they reached a density of approximately $10^{7}$ cells $/ \mathrm{ml}$ and approximately $8 \times 10^{5}$ cells $/ \mathrm{ml}$ were transferred to the new flask.

\section{A. marginale isolates}

The A. marginale isolate used for infection of $R$. microplus ticks and construction of SSH libraries was 
obtained from an infected calf in Texas, USA, in 1977. The isolate was subsequently passaged in splenectomized calves and blood samples were collected at the peak parasitemia (40\%), prepared as a stabilates with $10 \%$ DMSO and stored in $2 \mathrm{ml}$ aliquots in liquid nitrogen. A Brazilian strain of $A$. marginale with an inclusion appendage (UFMG1) [52], which was recently established and propagated in IDE8 tick cells, was used to infect BME26 cells [14].

\section{Uninfected and $A$. marginale-infected $R$. microplus male ticks for SSH libraries construction}

To obtain $A$. marginale-infected $R$. microplus male ticks, eight month-old non-splenectomized, tick-naive Holstein-Friesian calf (No.4280) was infected intravenously with the Texas isolate of $A$. marginale. $R$. microplus larvae were then fed on the calf with ascending parasitemia. Approximately 200 partially fed male ticks were collected after 21 days of feeding and the presence of A. marginale infection in salivary glands was confirmed in 20 individually dissected tick salivary glands by $m s p 4$ PCR [53]. Salivary glands from the remaining ticks were dissected in cold PBS, pooled and immediately stored in TriReagent (Sigma-Aldrich, Zwijndrecht, The Netherlands) at $-80^{\circ} \mathrm{C}$. Uninfected ticks were fed in a similar way on an uninfected calf and the male tick salivary glands were dissected and stored as described previously. Cattle and tick feeding studies were conducted in accordance with approval of the Animal Experiments Committee (DEC) of the Faculty of Veterinary Medicine, Utrecht University (DEC No. 0604.0801).

\section{Uninfected and $A$. marginale-infected cultured BME26 tick cells}

The tick cell line BME26 was cultured as described above. Approximately $4 \times 10^{6}$ cells from the passage 72 were plated in 24-well plates (Nunc) and maintained in Anaplasma medium [54] at $34^{\circ} \mathrm{C}$ for 3 days. The cells were infected with the 15 day-old culture of $A$. marginale in BME26 cells. Five milliliters of this suspension were transferred to a plastic tube. The tube was immersed in liquid nitrogen for $5 \mathrm{~min}$ for cell disruption and rickettsia releasing, followed by thawing in a water bath at $37^{\circ} \mathrm{C}$. Approximately $500 \mu \mathrm{l}$ of infected cell suspension was inoculated into each well onto uninfected BME26 monolayer. The plate was maintained at $34^{\circ} \mathrm{C}$ and cells harvested at 6, 24 and $72 \mathrm{hpi}$ from 4 wells for each time point. Uninfected control cells ( $\mathrm{n}=4$ wells) were cultured in the same way but with the addition of $500 \mu \mathrm{l}$ of Anaplasma medium only and the cells were harvested at the same time points. Cells were centrifuged at $800 \mathrm{~g}$ for $10 \mathrm{~min}$ and RNA/DNA was isolated using Trizol reagent (Gibco/Invitrogen), as recommended by the manufacturer. The infection of the tick cells by $A$. marginale was corroborated by msp4 PCR [53].

\section{Suppression-subtractive hybridization}

Total RNA was isolated from uninfected and A. marginale-infected tick salivary glands using Tri reagent (SigmaAldrich) following the manufacturer's protocol. RNA quality was checked by gel electrophoreses to confirm integrity of RNA preparations. Pools of $2 \mu \mathrm{g}$ of total RNA were made from uninfected and $A$. marginale-infected salivary glands. The cDNA synthesis was done using the Super SMART PCR cDNA synthesis kit (ClontechTakara, Saint-Germain-en-Laye, France), a method for producing high quality cDNA from a low amount of starting material. The cDNA was then directly used for PCR select subtraction (Clontech-Takara) based on a technique previously described by Diatchenko et al. $[14,15]$ and SSH libraries were constructed according to manufacturer's instructions. The double stranded cDNA from both groups (infected and uninfected salivary glands) was RsaI digested. Part of the digested cDNA was ligated with Adapter 1 and part with the Adapter 2R, and the rest was saved for use as a driver in preparation for hybridization. The forward subtracted library was made by hybridizing adapter ligated cDNA from $A$. marginaleinfected tick salivary glands as the tester in the presence of uninfected tick salivary gland CDNA as the driver. This forward reaction library was designed to produce clones that are overexpressed or up-regulated in infected salivary glands. The reverse library was made in the same way but in this case the adapter ligated cDNA from uninfected tick salivary glands was used as the tester and infected salivary gland cDNA as the driver. The reverse reaction library was designed to produce clones underexpressed or down-regulated in infected salivary glands. In either case the driver cDNA was added in excess during each hybridization to remove common cDNAs by hybrid selection and leaving over expressed and novel tester cDNA to be recovered and cloned. Differentially expressed cDNAs were PCR amplified with Advantage PCR polymerase mix (Clontech-Takara), cloned using pGEM Easy T/A cloning kit (Promega, Madison, WI, USA), transformed into JM109 and plated on LB with ampicillin, X-gal and IPTG. Approximately 300 clones were randomly picked up from each plated library in 96well plates containing LB medium supplemented with ampicillin and grown overnight. Plasmids were purified using Wizard SV 96 Plasmid DNA purification system (Promega). Plasmid inserts were PCR amplified and PCR products were fully sequenced in an accredited service laboratory (BaseClear, Leiden, The Netherlands) using vector specific primers.

\section{Sequence analysis and database search}

Partial sequences were obtained for 279 out of 576 randomly selected sequenced SSH library clones (288 from each forward- and reverse-subtracted libraries). The 
cDNA Annotation System software (CAS; Bioinformatics and Scientific IT Program (BSIP), Office of Technology Information Systems (OTIS), National Institute of Allergy and Infectious Diseases (NIAID), Bethesda, MD, USA) http://exon.niaid.nih.gov was used for automated sequence clean up, contig assembly, Blast analysis [55] against multiple sequence databases (nonredundant sequence database and databases of tick-specific sequences. (http://www.vectorbase.org/index.php and BmGI2; http://compbio.dfci.harvard.edu/), identification and locating of signal peptide cleavage sites and gene ontology (GO) assignments. Genes for further analyses were annotated by manual curation.

\section{Nucleotide sequence accession numbers}

The gene sequences reported in this paper are deposited in the GenBank Data Library under accession numbers: GO496166-G0496262.

\section{Real-time RT- PCR analysis}

The same RNA samples prepared before for SSH from uninfected and $A$. marginale-infected tick salivary glands were used for real-time RT-PCR. Total RNA was extracted as described above from uninfected and A. marginale-infected cultured BME26 tick cells from quadruplicate cultures at 6,24 and $72 \mathrm{hpi}$ and used for real-time RT-PCR. Oligonucleotide primers were synthesized based on the sequences determined for candidate differentially expressed genes (Table 3 ) and used in $25 \mu \mathrm{l}$ RT-PCR reactions performed using the iScript one step RT-PCR kit with SYBR green (Bio-Rad, Hercules, CA, USA) and a Bio-Rad iQ5 thermal cycler following the manufacturer's protocol. The mRNA levels were normalized against tick $\beta$-actin (Genbank accession number AY255624) using the comparative $C t$ method [56]. The mRNA levels were compared between infected and uninfected tick salivary glands and tick cells by Student's $t$ test $(\mathrm{p}=0.05)$. Total RNA was isolated from bovine blood and RT-PCR reactions were performed using the oligonucleotide primers and conditions described in Table 3. PCR products were electrophoretically separated using $1.5 \%$ agarose gel stained with ethidium bromide for visualization.

\section{RNA interference in ticks}

Oligonucleotide primers containing T7 promoter sequences at the 5 -end were synthesized for in vitro transcription of dsRNA using the Acess RT-PCR system (Promega, Madison, WI, USA) and the Megascript RNAi kit (Ambion, Austin, TX, USA) following manufacturer's instructions. The dsRNA was purified and quantified by spectophotometry. Newly molted uninfected $R$. microplus males, were injected with approximately $0.3 \mu \mathrm{l}$ of dsRNA $\left(5 \times 10^{10}\right.$ molecules $\left./ \mu \mathrm{l}\right)$ in the
Table 3 Real-time RT-PCR oligonucleotide primers and conditions

\begin{tabular}{|c|c|c|}
\hline EST & $\begin{array}{l}\text { Upstream/downstream } \\
\text { primer sequences }\left(5^{\prime}-3^{\prime}\right)\end{array}$ & $\begin{array}{l}\text { PCR annealing } \\
\text { conditions }\end{array}$ \\
\hline 7BstNI3 & $\begin{array}{l}\text { AAACTGGGGAATCCAAAAGG } \\
\text { GGGGTITGGGATAGGGTTC }\end{array}$ & $55^{\circ} \mathrm{C} / 30 \mathrm{~s}$ \\
\hline 9PRB2 & $\begin{array}{l}\text { AACGACCGCCCAAAAATAAC } \\
\text { AATITGTTCCGGTITGTTCC }\end{array}$ & $55^{\circ} \mathrm{C} / 30 \mathrm{~s}$ \\
\hline $22 \mathrm{Hbp}$ & $\begin{array}{l}\text { GGAGGTTACGAACTATGGGC } \\
\text { ATGAGTTGGCAGTGCCTAAG }\end{array}$ & $55^{\circ} \mathrm{C} / 30 \mathrm{~s}$ \\
\hline $281 \mathrm{mbpc}$ & $\begin{array}{l}\text { CGGTACCATGATGCACTITG } \\
\text { TGATGGCGTCCCTAGTTACC }\end{array}$ & $55^{\circ} \mathrm{C} / 30 \mathrm{~s}$ \\
\hline 36VATP & $\begin{array}{l}\text { GAAGGCTTCGAACAGAGTCG } \\
\text { CTCAATTCTGGTGGCCAAG }\end{array}$ & $55^{\circ} \mathrm{C} / 30 \mathrm{~s}$ \\
\hline 59Rib & $\begin{array}{l}\text { CCAGCAAGCGAGATTGTGTA } \\
\text { GCGTACTGTCTGAAGCAACG }\end{array}$ & $55^{\circ} \mathrm{C} / 30 \mathrm{~s}$ \\
\hline 88BstNI & $\begin{array}{l}\text { GTTGGGGGCCTTAAGAAAA } \\
\text { TाTTCCCAAAAGGTTCTCC }\end{array}$ & $55^{\circ} \mathrm{C} / 30 \mathrm{~s}$ \\
\hline 93 Meth & $\begin{array}{l}\text { CTGAACTGAACGCATCATGG } \\
\text { GCACAACATITTGCAGATGG }\end{array}$ & $55^{\circ} \mathrm{C} / 30 \mathrm{~s}$ \\
\hline 94Will & $\begin{array}{l}\text { TCATTGACGAAGAAGCGATC } \\
\text { TACAAGTCGCCCTGACACC }\end{array}$ & $55^{\circ} \mathrm{C} / 30 \mathrm{~s}$ \\
\hline 100Silk & $\begin{array}{l}\text { TGAACCAGAGGGACCAACTC } \\
\text { GTCTTGGACTCGGCAGTAGC }\end{array}$ & $55^{\circ} \mathrm{C} / 30 \mathrm{~s}$ \\
\hline $104 \mathrm{SrHb}$ & $\begin{array}{l}\text { CGAACCCGAATGGATTATG } \\
\text { TTCAAACATGAAGCGACAGC }\end{array}$ & $55^{\circ} \mathrm{C} / 30 \mathrm{~s}$ \\
\hline 108Kunz & $\begin{array}{l}\text { ATGGAACTGTTCGGTITGC } \\
\text { ATCCGCCGTAAATGAAGTTC }\end{array}$ & $55^{\circ} \mathrm{C} / 30 \mathrm{~s}$ \\
\hline 120Ptse & $\begin{array}{l}\text { GCGCGACCTCTITGTTAAAC } \\
\text { CGAATACGCACAGAAGGTGAC }\end{array}$ & $55^{\circ} \mathrm{C} / 30 \mathrm{~s}$ \\
\hline $128 \mathrm{Pec}$ & $\begin{array}{l}\text { AGGCCCAATTCTGATCTITC } \\
\text { CAAAGCTCAAACGTGTGGTG }\end{array}$ & $55^{\circ} \mathrm{C} / 30 \mathrm{~s}$ \\
\hline $\begin{array}{c}\text { Subolesin } \\
(4 \mathrm{D} 8)\end{array}$ & $\begin{array}{l}\text { GAGACCAGCCCCTGTTCA } \\
\text { CTGTTCTGCGAGTITGGTAGATAG }\end{array}$ & $54^{\circ} \mathrm{C} / 30 \mathrm{~s}$ \\
\hline Beta-actin & $\begin{array}{l}\text { GACATCAAGGAGAAGCT(TC)TGC } \\
\text { CGTTGCCGATGGTGAT(GC) }\end{array}$ & $55^{\circ} \mathrm{C} / 30 \mathrm{~s}$ \\
\hline
\end{tabular}

lower right quadrant of the ventral surface of the exoskeleton of the tick [19]. Ticks (35/group) were injected using a Hamilton syringe with a 1 inch, 33 gauge needle. Control ticks were injected with $R$. microplus subolesin dsRNA (positive control) or the unrelated GIII dsRNA (negative control). The GIII sequence was identified in $R$. microplus and did not affect tick feeding, mortality and oviposition after RNAi (unpublished results). Ticks were held in a humidity chamber for 3-5 hours and mortality was recorded before the living ticks were allowed to feed in seven separate patches (five test genes and two controls), each one for a different group, glued on the back of a calf naturally infected with $A$. marginale in Tamaulipas, Mexico (approximately $4 \%$ rickettsemia during tick feeding). Ten females were placed in each patch simultaneously with injected males. Unattached ticks were removed 2 days after infestation and attached ticks were allowed to feed for 7 days. All the males were collected and salivary glands were dissected 
from individual ticks from each group. The salivary glands were stored in RNAlater (Qiagen) until used for DNA and RNA extraction to determine $A$. marginale infection levels by quantitative $m s p 4$ PCR [53] and to confirm gene knockdown by real-time RT-PCR. The mRNA levels of the target gene and the A. marginale infection were compared between test and control ticks by Student's $t$-test $(\mathrm{p}=0.05)$. Tick mortality was evaluated as the ratio of the dead male ticks 7 days after dsRNA injection to the total number of attached male ticks feeding on the animal and was compared between test and control groups by $\chi^{2}$-test $(\alpha=0.025)$.

\section{RNA interference in cultured BME26 tick cells}

Approximately $5 \times 10^{5}$ BME26 cells/well were placed in 24-well plates (Nunc). The dsRNA prepared in the way described above for each of the 8 target genes was added to the culture wells ( $\mathrm{n}=4$ for each treatment). Subolesin dsRNA was used as a positive control and control wells received elution buffer only. Each of the treated wells received $10 \mu \mathrm{l}$ of dsRNA $\left(5 \times 10^{10}\right.$ molecules per microliter) and $190 \mu \mathrm{l}$ of L15B Anaplasma medium and was incubated for $24 \mathrm{~h}$. After this period, additional $300 \mu \mathrm{l}$ of medium were added to each well. After $48 \mathrm{~h}$ cells were infected as described above. Three days post infection the cells were harvested from the plate, centrifuged at $800 \times \mathrm{g}$ for $10 \mathrm{~min}$ and used to extract RNA and DNA with TriReagent (Sigma). $A$. marginale infection levels were determined by msp 4 PCR [53]. Gene expression silencing was confirmed by real-time RT-PCR using sequence-specific primers (Table 3) as described above.

Additional file 1: Genes identified by SSH as differentially expressed in $A$. marginale-infected $R$. microplus male salivary glands.

Click here for file

[http://www.biomedcentral.com/content/supplementary/1471-2164-11186-S1.DOC ]

Additional file 2: Differentially expressed genes selected based on their putative role during $A$. marginale infection to validate SSH results by real-time RT-PCR.

Click here for file

[http://www.biomedcentral.com/content/supplementary/1471-2164-11186-S2.DOC ]

\section{Acknowledgements}

This research was supported by grants from the European Community, INCO-DEV program (project no. 003713), entitled 'Epidemiology and new generation vaccines for Ehrlichia and Anaplasma infections of ruminants', the Ministerio de Ciencia e Innovación, Spain (project BFU2008-01244/BMC), the CSIC intramural project 2008301249 to JF, FAPESP (Fundação de Amparo a Pesquisa do Estado de São Paulo, Brazil), and CNPq (Conselho Nacional de Desenvolvimento Científico e Tecnológico, Brazil) and was facilitated through the Integrated Consortium on Ticks and Tick-borne Diseases (ICTTD3), financed by the International Cooperation Program of the European Union, coordination action project No. 510561. We are grateful to Biankynet Gonzalez for the technical assistance.

\section{Author details}

'Department of Infectious Diseases and Immunology, Utrecht Centre for Tick-borne Diseases (UCTD), Faculty of Veterinary Medicine, Utrecht University, Yalelaan 1, 3584CL, Utrecht, the Netherlands. ${ }^{2}$ Departamento de Parasitologia, Instituto de Ciências Biomédicas, Universidade de São Paulo, Av. Prof. Lineu Prestes, 1374, CEP 05508-900, São Paulo, Brazil. ${ }^{3}$ Facultad de Medicina Veterinaria y Zootecnia, Universidad Autónoma de Tamaulipas, Km.5 carretera Victoria-Mante, CP 87000 Cd. Victoria, Tamaulipas, Mexico. ${ }^{4}$ Department of Veterinary Pathobiology, Center for Veterinary Health Sciences, Oklahoma State University, Stillwater, OK 74078, USA. ${ }^{5}$ Department of Veterinary Tropical Diseases, Faculty of Veterinary Science, University of Pretoria, Private Bag X04, 0110, Onderstepoort, South Africa. Instituto de Investigación en Recursos Cinegéticos IREC (CSIC-UCLM-JCCM), Ronda de Toledo s/n, 13005 Ciudad Real, Spain.

\section{Authors' contributions}

ZZ prepared SSH libraries, participated in sequence analyses, did the molecular work and drafted the manuscript. EE did the cell culture work and helped with drafting the manuscript. CA helped with the tick RNAi experiments and revision of the manuscript. AN helped with tick infection experiment and revision of the manuscript. SD and KK helped with drafting and revision of the manuscript. FJ and JF participated in design and coordination of the study and helped with drafting and revision of the manuscript. Jf contributed to acquisition of molecular biology data. All authors read and approved the final manuscript.

Received: 14 April 2009 Accepted: 18 March 2010

Published: 18 March 2010

\section{References}

1. Kocan KM, de la Fuente J, Guglielmone AA, Melendez RD: Antigens and alternatives for control of Anaplasma marginale infection in cattle. Clin Microbiol Rev 2003, 16(4):698-712.

2. Kocan KM, de la Fuente J, Blouin EF, Garcia-Garcia JC: Anaplasma marginale (Rickettsiales: Anaplasmataceae): recent advances in defining host-pathogen adaptations of a tick-borne rickettsia. Parasitology 2004, 129(Suppl):S285-300.

3. Guerrero FD, Nene VM, George JE, Barker SC, Willadsen P: Sequencing a new target genome: the Boophilus microplus (Acari: Ixodidae) genome project. J Med Entomol 2006, 43(1):9-16.

4. de Castro Jj: Sustainable tick and tickborne disease control in livestock improvement in developing countries. Vet Parasitol 1997, 71(2-3):77-97.

5. Kocan KM, Goff WL, Stiller D, Claypool PL, Edwards W, Ewing SA, Hair JA, Barron SJ: Persistence of Anaplasma marginale (Rickettsiales: Anaplasmataceae) in male Dermacentor andersoni (Acari: Ixodidae) transferred successively from infected to susceptible calves. J Med Entomol 1992, 29(4):657-668.

6. Kocan KM, Stiller D, Goff WL, Claypool PL, Edwards W, Ewing SA, McGuire TC, Hair JA, Barron SJ: Development of Anaplasma marginale in male Dermacentor andersoni transferred from parasitemic to susceptible cattle. Am J Vet Res 1992, 53(4):499-507.

7. Chevillon C, Koffi BB, Barre N, Durand P, Arnathau C, de Meeus T: Direct and indirect inferences on parasite mating and gene transmission patterns. Pangamy in the cattle tick Rhipicephalus (Boophilus) microplus. Infect Genet Evol 2007, 7(2):298-304.

8. Macaluso KR, Mulenga A, Simser JA, Azad AF: Differential expression of genes in uninfected and rickettsia-infected Dermacentor variabilis ticks as assessed by differential-display PCR. Infect Immun 2003, 71(11):6165-6170.

9. Nene V, Lee D, Kang'a S, Skilton R, Shah T, de Villiers E, Mwaura S, Taylor D, Quackenbush J, Bishop R: Genes transcribed in the salivary glands of female Rhipicephalus appendiculatus ticks infected with Theileria parva. Insect Biochem Mol Biol 2004, 34(10):1117-1128.

10. Rudenko N, Golovchenko M, Edwards MJ, Grubhoffer L: Differential expression of Ixodes ricinus tick genes induced by blood feeding or Borrelia burgdorferi infection. J Med Entomol 2005, 42(1):36-41.

11. de la Fuente J, Kocan KM, Almazan C, Blouin EF: RNA interference for the study and genetic manipulation of ticks. Trends Parasitol 2007, 23(9):427-433. 
12. Bell-Sakyi L, Zweygarth E, Blouin EF, Gould EA, Jongejan F: Tick cell lines: tools for tick and tick-borne disease research. Trends Parasitol 2007, 23(9):450-457

13. Esteves E, Bastos CV, Zivkovic Z, de La Fuente J, Kocan K, Blouin E, Ribeiro MF, Passos LM, Daffre S: Propagation of a Brazilian isolate of Anaplasma marginale with appendage in a tick cell line (BME26) derived from Rhipicephalus (Boophilus) microplus. Vet Parasitol 2008, 161(1-2):150-3.

14. Diatchenko L, Lukyanov S, Lau YF, Siebert PD: Suppression subtractive hybridization: a versatile method for identifying differentially expressed genes. Methods Enzymol 1999, 303:349-380.

15. Diatchenko L, Lau YF, Campbell AP, Chenchik A, Moqadam F, Huang B, Lukyanov S, Lukyanov K, Gurskaya N, Sverdlov ED, et al: Suppression subtractive hybridization: a method for generating differentially regulated or tissue-specific cDNA probes and libraries. Proc Natl Acad Sci USA 1996, 93(12):6025-6030.

16. Pal U, Li X, Wang T, Montgomery RR, Ramamoorthi N, Desilva AM, Bao F, Yang X, Pypaert M, Pradhan D, et al: TROSPA, an Ixodes scapularis receptor for Borrelia burgdorferi. Cell 2004, 119(4):457-468.

17. Ramamoorthi N, Narasimhan S, Pal U, Bao F, Yang XF, Fish D, Anguita J, Norgard MV, Kantor FS, Anderson JF, et al: The Lyme disease agent exploits a tick protein to infect the mammalian host. Nature 2005 436(7050):573-577.

18. Sukumaran B, Narasimhan S, Anderson JF, DePonte K, Marcantonio N, Krishnan MN, Fish D, Telford SR, Kantor FS, Fikrig E: An Ixodes scapularis protein required for survival of Anaplasma phagocytophilum in tick salivary glands. J Exp Med 2006, 203(6):1507-1517

19. de la Fuente J, Almazan C, Blouin EF, Naranjo V, Kocan KM: Reduction of tick infections with Anaplasma marginale and A. phagocytophilum by targeting the tick protective antigen subolesin. Parasitol Res 2006, 100(1):85-91

20. de la Fuente J, Lew A, Lutz H, Meli ML, Hofmann-Lehmann R, Shkap V, Molad T, Mangold AJ, Almazan C, Naranjo V, et al: Genetic diversity of anaplasma species major surface proteins and implications for anaplasmosis serodiagnosis and vaccine development. Anim Health Res Rev 2005, 6(1):75-89.

21. Brayton KA, Kappmeyer LS, Herndon DR, Dark MJ, Tibbals DL, Palmer GH, McGuire TC, Knowles DP Jr: Complete genome sequencing of Anaplasma marginale reveals that the surface is skewed to two superfamilies of outer membrane proteins. Proc Natl Acad Sci USA 2005, 102(3):844-849.

22. de la Fuente J, Kocan KM, Almazan C, Blouin EF: Targeting the tickpathogen interface for novel control strategies. Front Biosci 2008, 13:6947-6956.

23. Bishop R, Lambson B, Wells C, Pandit P, Osaso J, Nkonge C, Morzaria S, Musoke A, Nene V: A cement protein of the tick Rhipicephalus appendiculatus, located in the secretory e cell granules of the type III salivary gland acini, induces strong antibody responses in cattle. Int $J$ Parasitol 2002, 32(7):833-842.

24. Paesen GC, Adams PL, Harlos K, Nuttall PA, Stuart DI: Tick histaminebinding proteins: isolation, cloning, and three-dimensional structure. $\mathrm{Mol}$ Cell 1999, 3(5):661-671

25. Labuda M, Trimnell AR, Lickova M, Kazimirova M, Davies GM, Lissina O, Hails RS, Nuttall PA: An antivector vaccine protects against a lethal vector-borne pathogen. PLoS Pathog 2006, 2(4):e27.

26. Hayashi $C Y$, Lewis RV: Molecular architecture and evolution of a modular spider silk protein gene. Science 2000, 287(5457):1477-1479.

27. Alarcon-Chaidez FJ, Sun J, Wikel SK: Transcriptome analysis of the salivary glands of Dermacentor andersoni Stiles (Acari: Ixodidae). Insect Biochem Mol Biol 2007, 37(1):48-71.

28. Santos IK, Valenzuela JG, Ribeiro JM, de Castro M, Costa JN, Costa AM, da Silva ER, Neto OB, Rocha C, Daffre S, et al: Gene discovery in Boophilus microplus, the cattle tick: the transcriptomes of ovaries, salivary glands, and hemocytes. Ann N Y Acad Sci 2004, 1026:242-246.

29. Mulenga A, Blandon M, Khumthong R: The molecular basis of the Amblyomma americanum tick attachment phase. Exp Appl Acarol 2007, 41(4):267-287.

30. Donohue KV, Khalil SM, Mitchell RD, Sonenshine DE, Roe RM: Molecular characterization of the major hemelipoglycoprotein in ixodid ticks. Insect Mol Biol 2008, 17(3):197-208.

31. Almazan C, Kocan KM, Bergman DK, Garcia-Garcia JC, Blouin EF, de la Fuente J: Identification of protective antigens for the control of Ixodes scapularis infestations using cDNA expression library immunization. Vaccine 2003, 21(13-14):1492-1501.

32. de la Fuente J, Almazan C, Blas-Machado U, Naranjo V, Mangold AJ Blouin EF, Gortazar C, Kocan KM: The tick protective antigen, 4D8, is a conserved protein involved in modulation of tick blood ingestion and reproduction. Vaccine 2006, 24(19):4082-4095

33. Almazan C, Blas-Machado U, Kocan KM, Yoshioka JH, Blouin EF, Mangold AJ, de la Fuente J: Characterization of three Ixodes scapularis CDNAs protective against tick infestations. Vaccine 2005, 23(35):4403-4416.

34. Almazan C, Kocan KM, Blouin EF, de la Fuente J: Vaccination with recombinant tick antigens for the control of Ixodes scapularis adult infestations. Vaccine 2005, 23(46-47):5294-5298.

35. de la Fuente J, Almazan C, Naranjo V, Blouin EF, Meyer JM, Kocan KM: Autocidal control of ticks by silencing of a single gene by RNA interference. Biochem Biophys Res Commun 2006, 344(1):332-338.

36. Nijhof AM, Taoufik A, de la Fuente J, Kocan KM, de Vries E, Jongejan F: Gene silencing of the tick protective antigens, Bm86, Bm91 and subolesin, in the one-host tick Boophilus microplus by RNA interference. Int J Parasitol 2007, 37(6):653-662.

37. Kocan KM, Manzano-Roman $\mathrm{R}$, de la Fuente J: Transovarial silencing of the subolesin gene in three-host ixodid tick species after injection of replete females with subolesin dsRNA. Parasitol Res 2007, 100(6):1411-1415.

38. de la Fuente J, Maritz-Olivier C, Naranjo V, Ayoubi P, Nijhof AM, Almazan C, Canales M, Perez de la Lastra JM, Galindo RC, Blouin EF, et al: Evidence of the role of tick subolesin in gene expression. BMC Genomics 2008, $9(1): 372$

39. Galindo RC, Doncel-Perez E, Zivkovic Z, Naranjo V, Gortazar C, Mangold A Martin-Hernando MP, Kocan KM, de la Fuente J: Tick subolesin is an ortholog of the akirins described in insects and vertebrates. Dev Comp Immunol 2009, 33(4):612-617.

40. de la Fuente J, Blouin EF, Manzano-Roman R, Naranjo V, Almazan C, Perez de la Lastra JM, Zivkovic Z, Massung RF, Jongejan F, Kocan KM: Differential expression of the tick protective antigen subolesin in anaplasma marginale- and A. phagocytophilum-infected host cells. Ann N Y Acad Sci 2008, 1149:27-35.

41. Borghesi LA, Lynes MA: Stress proteins as agents of immunological change: some lessons from metallothionein. Cell Stress Chaperones 1996, 1(2):99-108.

42. Dallinger R: Metallothionein research in terrestrial invertebrates: synopsis and perspectives. Comp Biochem Physiol C Pharmacol Toxicol Endocrinol 1996, 113(2):125-133

43. Dutsch-Wicherek M, Sikora J, Tomaszewska R: The possible biological role of metallothionein in apoptosis. Front Biosci 2008, 13:4029-4038.

44. Mannick EE, Schurr JR, Zapata A, Lentz JJ, Gastanaduy M, Cote RL, Delgado A, Correa P, Correa H: Gene expression in gastric biopsies from patients infected with Helicobacter pylori. Scand J Gastroenterol 2004, 39(12):1192-1200.

45. Wiese L, Kurtzhals JA, Penkowa M: Neuronal apoptosis, metallothionein expression and proinflammatory responses during cerebral malaria in mice. Exp Neurol 2006, 200(1):216-226.

46. Baerwald MR, Welsh AB, Hedrick RP, May B: Discovery of genes implicated in whirling disease infection and resistance in rainbow trout using genome-wide expression profiling. BMC Genomics 2008, 9:37.

47. Hirano T, Murakami M, Fukada T, Nishida K, Yamasaki S, Suzuki T: Roles of zinc and zinc signaling in immunity: zinc as an intracellular signaling molecule. Adv Immunol 2008, 97:149-176.

48. Uzarowska A, Dionisio G, Sarholz B, Piepho HP, Xu M, Ingvardsen CR, Wenzel $G$, Lubberstedt $T$ : Validation of candidate genes putatively associated with resistance to SCMV and MDMV in maize (Zea mays L.) by expression profiling. BMC Plant Biol 2009, 9:15

49. Saldivar L, Guerrero FD, Miller RJ, Bendele KG, Gondro C, Brayton KA: Microarray analysis of acaricide-inducible gene expression in the southern cattle tick, Rhipicephalus (Boophilus) microplus. Insect Mol Biol 2008, 17(6):597-606.

50. Kurtti TJ, Munderloh UG, Ahlstrand GG, Johnson RC: Borrelia burgdorferi in tick cell culture: growth and cellular adherence. J Med Entomol 1988, 25(4):256-261

51. Munderloh UG, Jauron SD, Fingerle V, Leitritz L, Hayes SF, Hautman JM, Nelson CM, Huberty BW, Kurtti TJ, Ahlstrand GG, et al: Invasion and intracellular development of the human granulocytic ehrlichiosis agent in tick cell culture. J Clin Microbiol 1999, 37(8):2518-2524. 
52. Ribeiro MF, Passos LM, Guimaraes AM: Ultrastructure of Anaplasma marginale with an inclusion appendage, isolated in Minas Gerais State, Brazil. Vet Parasitol 1997, 70(4):271-277.

53. de la Fuente J, Garcia-Garcia JC, Blouin EF, McEwen BR, Clawson D, Kocan KM: Major surface protein 1a effects tick infection and transmission of Anaplasma marginale. Int J Parasitol 2001, 31(14):1705-1714.

54. Munderloh UG, Blouin EF, Kocan KM, Ge NL, Edwards WL, Kurtti TJ: Establishment of the tick (Acari:Ixodidae)-borne cattle pathogen Anaplasma marginale (Rickettsiales:Anaplasmataceae) in tick cell culture. $J$ Med Entomol 1996, 33(4):656-664.

55. Altschul SF, Gish W, Miller W, Myers EW, Lipman DJ: Basic local alignment search tool. J Mol Biol 1990, 215(3):403-410.

56. Schefe JH, Lehmann KE, Buschmann IR, Unger T, Funke-Kaiser $\mathrm{H}$ : Quantitative real-time RT-PCR data analysis: current concepts and the novel "gene expression's CT difference" formula. J Mol Med 2006, 84(11):901-910.

doi:10.1186/1471-2164-11-186

Cite this article as: Zivkovic et al.: Differential expression of genes in salivary glands of male Rhipicephalus (Boophilus)microplus in response to infection with Anaplasma marginale. BMC Genomics 2010 11:186.

\section{Submit your next manuscript to BioMed Central} and take full advantage of:

- Convenient online submission

- Thorough peer review

- No space constraints or color figure charges

- Immediate publication on acceptance

- Inclusion in PubMed, CAS, Scopus and Google Scholar

- Research which is freely available for redistribution

Submit your manuscript at www.biomedcentral.com/submit
C Biomed Central 